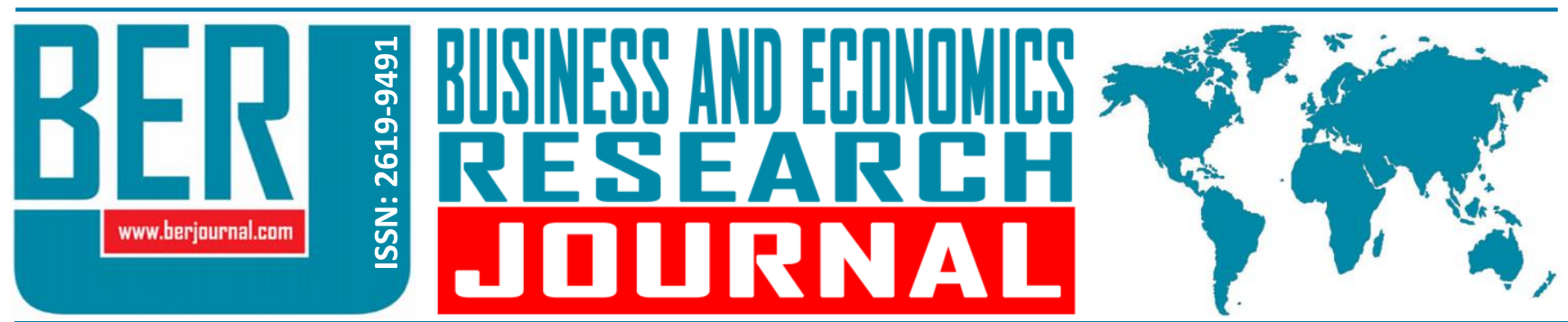

Business and Economics Research Journal Vol. 11, No. 2, 2020, pp. 353-369 doi: 10.20409/berj.2020.254

\section{Türkiye'de İç Göçü Etkileyen Faktörler: Mekânsal Panel Veri Analizi}

\author{
Hakan Ondes ${ }^{\mathrm{a}}$, Ozlem Ayvaz Kizilgol ${ }^{\mathrm{b}}$
}

Öz: Birçok farklı olguyu içinde barındıran göç, esas olarak ekonomik, çevresel, sosyal ve kültürel açıdan sonuçlara neden olmaktadır. Bu çalışma, Türkiye'deki göç hareketlerinde itici ve çekici etmenlerin etkisini incelemektedir. Türkiye'nin iBBS Düzey 1'de yer alan 12 alt bölgesinde 20082017 dönemleri için çeşitli değişkenlerin iç göç üzerindeki etkileri, bölgeler arası mekânsal ilişkiyi göz önünde bulunduran mekânsal panel veri modelleriyle ele alınmıştır. Bölgeler göç alan ve göç veren olarak ikiye ayrılmış ve modellerde yer alan değişkenlerin etkisi ayrı ayrı incelenmiştir. Çalışmanın bulguları, Türkiye'de göç alan ve göç veren bölgelerde mekânsal ilişkinin olduğunu, bir başka ifadeyle komşu bölgenin göç yapısının, ilgili bölgenin göç hareketinde de anlamlı bir etkiye sahip olduğunu göstermektedir. Ek olarak göç alan bölgelerde, bölgenin kişi başına düşen gelirinin Türkiye ortalamasından fazla olması, istihdamın artması, işlenen tarım alanlarının çeşitliliği ile gö̧ arasında pozitif yönlü bir ilişki elde edilmiştir. Göç veren bölgelerde ise, işsizlik, ithalat ve kişi başına düşen gelir anlamlı itici faktörlerin başında gelmektedir. Özellikle sağlık ve eğitim alanında yaşanan geri kalmışık gö̧ veren bölgelerin en önemli sorunu olmuştur. Ayrıca, elverişli tarım alanlarının yetersizliği ve bu alanda gelir elde edilememesi bu bölgelerde yaşayan nüfusun göc etmesinde önemli bir etken olmuştur.

\section{Analysis of Factors Affecting Internal Migration in Turkey: Spatial Panel Data Analysis}

Abstract: Immigration, which includes many different phenomena, results mainly in economic, environmental, social and cultural aspects. This study examines the effect of push and pull factors of internal migration in Turkey. In the 12 sub-regions of NUTS Level 1, the effects of various variables on internal migration for the period 2008-2017 were handled with spatial panel data models considering the spatial relationship between regions. Regions were divided into two groups as migration and emitter and the effects of the variables in the models were examined separately. Findings of the study, there are spatial relations in the field of emigration and immigration in Turkey. In other words, it shows that the migration structure of the neighboring region has a significant effect on the migration movement of the related region. Migration in regions, is more than Turkey's average per capita income, increased employment and diversity of processed agricultural fields was obtained a positive relationship between migration. In migration regions, unemployment, imports and per capita income are the leading drivers. In particular, backwardness in the field of health and education has been the most important problem of the migrant regions. In addition, the insufficiency of suitable agricultural areas and the inability to generate income in this area have been an important factor in the migration of the population living in these regions.
Anahtar Sözcükler: İç Göç, Sosyo-Ekonomik Faktörler, Mekânsal Bağımlılık, Sabit Etkili Mekânsal Hata Modeli, Türkiye

JEL: C23, O15, R23

$\begin{array}{ll}\text { Geliş } & : 07 \text { Ocak } 2020 \\ \text { Düzeltme } & : 19 \text { Şubat } 2020 \\ \text { Kabul } & : 09 \text { Mart } 2020 \\ \text { Tür } & \text { : Araştırma }\end{array}$

Keywords: Internal Migration, Socio-Economic Factors, Spatial Dependence, Fixed Effect Spatial Error Model, Turkey

JEL: C23, 015, R23

$\begin{array}{ll}\text { Received } & : 07 \text { January } 2020 \\ \text { Revised } & : \text { 19 February } 2020 \\ \text { Accepted } & : 09 \text { March } 2020 \\ \text { Type } & : \text { Research }\end{array}$

Type : Research

a Res. Asst. Bandirma Onyedi Eylul University, Faculty of Economics and Administrative Sciences, Department of Econometrics, Balikesir, Turkiye, hondes@bandirma.edu.tr (ORCID: 0000-0002-0618-7705)

b Asst. Prof., PhD., Bandirma Onyedi Eylül University, Faculty of Economics and Administrative Sciences, Department of Econometrics, Balikesir, Turkiye, okizilgol@bandirma.edu.tr (ORCID: 0000-0001-9996-7892) 


\section{Giriş}

Farklı tanımlamaları olmakla birlikte göç, temelde, ekonomik, sosyal, kültürel, siyasi, dini, doğal afetler ve güvenlik gibi sebeplerle ya da iyi bir yaşam beklentisi nedeniyle veya herhangi bir nedenle, isteyerek ya da zorla, bireylerin veya toplulukların yaşamlarının bir bölümünü ya da tamamını geçirmek üzere yani geçici veya sürekli olarak (Birleşmiş Milletler tarafından göçün "sürekli olması" bir yıldan fazla süre olarak kabul edilmektedir) yaşadıkları ortamları bırakıp, bir ülkeden başka bir ülkeye, bir yerleşim yerinden başka bir yerleşim yerine kitleler halinde ya da bireyler bazında yapmış oldukları coğrafi nitelikli yer değiştirme olayı veya bir nüfus hareketi olarak tanımlanabilir (Kalkınma Bakanlığı, 2014: 1; Şen, 2014: 233; Karakayacı vd., 2018: 523). Göç olgusunun temelinde birey bulunmakla beraber ortaya çıkardığı sonuçlar toplumsal olduğundan, fiziksel bir hareketlilik olmasının yanı sıra toplumsal bir olgudur (Özcan, 2016: 185).

Göçün çok farklı türleri mevcuttur ve farklı alanlara göre gruplandırılabilmektedir. Göç sosyoekonomik açıdan, iç göç ve dış göç olarak ikiye ayrılabilir. Bireyin veya toplulukların, bir ülke sınırları içerisinde bir yıldan az olmamak kaydıyla yaşadığı ortamı değiştirmesi iç göç, bireyin veya toplulukların bir ülkeden başka bir ülkeye giderek yaşadığı ortamı değiştirmesi ise dış göç olarak adlandırılır (Bindak, 2015: 112). İç göç, nüfusun ülke, bölge ve şehir içinde yer değiştirmesidir. İç göçlerde ülke nüfusunda herhangi bir değişim olmamakla birlikte bölgelerdeki ve şehirlerdeki nüfus oranlarında değişim söz konusudur (Temel, 2017: 12). Ekonomik kalkınmışık düzeyi, ülkelerin büyüklüğü ve yerleşme tarihlerine bağlı olarak iç göç hareketi sadece kırsal kesimden şehirlere doğru değil, kırsal kesimden kırsal kesime doğru, şehirlerden kırsal kesime doğru ve şehirlerden şehirlere doğru da gerçekleşmektedir (Anavatan, 2017: 1110)

Türkiye'de ekonomik ve toplumsal dönüşümle birlikte özellikle 1980'li yıllardan itibaren artış gösteren iç göç, nedenleri ve belirleyicileri ile birlikte ele alınması gereken önemli bir sorun haline gelmiştir. Literatürde, iç göç kararı üzerinde başlangıçta tamamen ekonomik unsurların etkili olduğu düşünülürken, daha sonraki dönemlerde hem ekonomik hem de ekonomik olmayan unsurların iç göç kararı üzerinde etkili olduğu görülmüş, bunlar arasındaki ilişkilerin göç üzerindeki önemi araştırılmış ve detaylı bir şekilde analiz edilmeye çalışılmıştır (Çetin ve Çetin, 2018: 99). İ̧̧ göçün gelişimini ve etkili olan faktörleri tek taraflı olarak değerlendirmek yanıltıcı olabilir. Bu durumda, göç alan ve göç veren bölgelerin sahip oldukları özelliklerin belirlenmesi ve göçü belirleyen unsurların bu bölgelerin özellikleri ile birlikte analiz edilmesi gerekmektedir. İ̧ göç analizlerinde göç alan bölgelerin göç alma nedenlerinin tespit edilmesi, bunu belirleyen etkenlerin ortaya konması, göç alan bölgelerin nüfus artışlarının kontrol altında tutulmasında ve bu bölgelerde ortaya çıkacak sorunların giderilebilmesi için gerekli düzenlemelerin yapılmasında önemlidir. Göç veren bölgelerin ise göç verme nedenlerinin belirlenmesi, bu bölgelerde mevcut olan sorunların giderilmesine yönelik çeşitli alanlarda ihtiyaç duyulan programların oluşturulmasında önemlidir. Bunlar açısından bakıldı̆̆ında bu çalışma literatüre katkı sağlamaktadır. Türkiye'de iç göç ile ilgili olarak yapılan ampirik çalışmalarda panel veri kullanarak mekânsal etkileşimi inceleyen birkaç tane çalışmaya rastlanılmıştır. Bu anlamda göç alan ve göç veren bölgelerde göç hareketini etkileyen etmenlerin ne ölçüde değişiklik oluşturacağı problematiğinin cevaplanması literatürdeki eksikliği dolduracaktır. Bu çalışmanın amacı, Türkiye'de iç göçe neden olan sosyoekonomik faktörlerin belirlenmesidir. Bu amaç doğrultusunda Türkiye'nin iBBS Düzey 1'de yer alan 12 alt bölgesinde, bölgeler arasındaki göçü etkileyen başlıca faktörler mekânsal etkileşimi dikkate alan mekânsal panel veri analizi kullanılarak 2008-2017 yılları için araştırılmıştır. Böylece göç üzerinde etkili olan temel sosyo-ekonomik değişkenlerin yanında bölgeler arası göçte mekânsal bağımlılığın olup olmadığı da araştırımıştır. Bu araştırmanın yönü, çalışmanın mevcut çalışmalara yönelik özgünlüğünü ortaya koymaktadır.

Çalışmanın diğer bölümleri şu şekilde ele alınmıştır: ikinci bölümde Türkiye'de iç göçün gelişimi ve bölgeler arasındaki iç göç hareketleri ele alınacak, üçüncü bölümde iç göçün nedenleri ortaya konulmaya çalışılacak, dördüncü bölümde iç göçü belirleyen unsurları ampirik olarak analiz eden çalışmalar incelenecek, beşinci bölümde analizde kullanılan veri seti ve değişkenler tanıtılacak, yöntem hakkında bilgi verilecek ve analiz sonuçları yorumlanacak, altıncı bölümde ise sonuç ve önerilere yer verilecektir. 


\section{Türkiye'de İç Göç Olgusu}

İ̧̧ göç geçmişten günümüze kadar yıllar itibariyle birçok ülkenin temel sorunlarından birini teşkil etmiştir. Türkiye'de de göç olgusu uzun yıllardır devam eden önemli yapısal problemlerden birisidir. 20. yüzyııı ortalarında başlayan ekonomik ve sosyal alandaki gelişmelere bağlı olarak, nüfusun mekânsal dağııımında ve demografik yapıda önemli değişimler yaşanmıştır. Özellikle 1950 yılından sonra nüfus artışıyla beraber ülkenin yerleşim şekli ve nüfus hareketleri hızlanmaya başlamıştır (Bülbül ve Köse, 2010: 76; Albayrak ve Abdioğlu, 2017: 294). Bu dönemde genel olarak tarım toplumu olma özelliği gösteren ülkenin modernleşmeye ve sanayileşmeye başlamasıyla birlikte, toplumsal yapısında oldukça önemli değişim ve dönüşümlerin ortaya çıktığı görülmektedir (Dücan, 2016: 169). Söz konusu dönemden günümüze kadar devam eden süreç içinde yaşanan hareketlilik, göç alan ve göç veren bütün bölgelerin sosyal, ekonomik ve kültürel değişiminde göz ardı edilemeyecek ciddi bir rol oynamıştır.

Türkiye'de iç göç hareketleri 1923-1950, 1950-1980 ve 1980 sonrası dönem olarak üç dönem şeklinde sınıflandırılabilir. Böyle bir sınıflandırma yapılmasının nedeni, iç göçün yaşanmadığı yılların (1923-1950), iç göçün başladığı yılların (1950-1980) ve iç göçün artış gösterdiği yılların incelenmesi ve iç göçe neden olan faktörlerin belirlenmesidir. 1923-1950 arası dönemde bölgesel göç hareketlerinin yok denecek kadar az olduğu görülmektedir. 1950-1980 arası dönemde ve 1980'den sonraki dönemde ise iç göç hareketlerinin başladığı ve yoğunlaştığı görülmektedir. Türkiye'de iç göçün yaşanmaya başlaması 1950 yılından sonra olmuştur. i̇kinci Dünya Savaşı'nı takiben bu yıllarda sanayileşmenin hız kazanması ve ekonomik canlanma ile birlikte Türkiye'de iç göç önemli bir olgu olarak ortaya çıkmıştır. Sanayileşme süreci ve ekonomideki gelişmeler sonucunda sanayi sektöründe ihtiyaç duyulan işgücünü kırsal kesimdeki nüfus oluşturmuştur. Bu durum kırsal alanlardan şehirlere doğru işgücü akımına dolayısıyla iç göçe neden olmuştur (Pazarlıoğlu, 2007: 122; Akseki ve Türkcan, 2016: 1872). 1950'li yıllarda başlayan iç göç hareketleri kırdan kente göç biçiminde iken, zamanla değişiklik göstererek kentten kente göç biçimine dönüşmüştür. 1950-1980 dönemindeki göç hareketleri ekonomideki yapısal değişimin bir itici güç olmasından kaynaklanmış, diğer taraftan 1980'den sonraki dönemde başlayan göç hareketleri ise ulaşım ve haberleşme teknolojisindeki gelişmelerin iletici güçler olarak ortaya çıkmasından kaynaklanmıştır (Akseki ve Türkcan, 2016: 1873).

Dünyanın birçok ülkesinde olduğu gibi Türkiye'nin de asıl yapısal sorunlarından birisi bölgesel gelişmişlik farklılıklarıdır. Bölgeler arası ve bölge içi gelişmişlik farklılıklarının mevcut olması ve bu farklılıkların uzun yıllar boyunca sürmesi, Türkiye'de iç göçün temel nedenidir. Öte yandan, iç göç sosyal ve ekonomik faaliyetlerin belirli bölgelerde yoğunlaşmasına paralel olarak ülke içinde bölgesel farklılıkların ve dengesizliklerin ortaya çıkmasına neden olmaktadır (Özdemir, 2018: 1338). Böylece bölgeler arası farklııklar hem iç göçün nedeni hem de sonucu olarak kısır döngüye yol açmaktadır. Dolayısıyla üretilen toplumsal refahın dengesiz dağıtılması hem göçe neden olmakta hem de yerleşim yerlerinde farklılıkların ortaya çıkmasına neden olmaktadır (Sevinç vd., 2018: 75). Türkiye'de iç göçün yıllara göre olan değişimi izlenebilmektedir. 1950 yılında Türkiye'deki il sayısı 63'dür ve kentlerde yaşayan nüfus oranı \%18,1'dir (Ankara Kalkınma Ajansı, 2014: 13). 1980'li yıllardan itibaren ülkede uygulamaya konulan yeni liberal ekonomi ve tarım politikalarına paralel olarak kırsal alanlardan kentlere göç hızlanmıştır (Aşkın vd., 2013: 232). 1990 yılında il sayısı 73, kentsel nüfus oranı \%56,3 olmuştur (Ankara Kalkınma Ajansı, 2014: 13). 2000 yılında il sayısı 81'dir. Kentsel nüfus toplam nüfusun \%65'ini oluştururken (Kalkınma Bakanlığı, 2014: 26), bu oran 2010 yılında \%76'ya yükselmiştir. 2018 yılında ise il sayısı 81'dir ve kentsel nüfus oranı \%92 olmuştur (tuik.gov.tr).

Türkiye'de iç göç olgusunun yapısının anlaşıımasında ve iç göç hareketlerinin belirlenmesinde, bölgesel göçün coğrafik olarak bir yönünün olup olmadığını saptamak önemlidir. Bölgeler arası göçün yönünün belirlenmesinde ise bölgelerin aldığı ve verdiği göç sayıları tespit edilebilir. Örneğin 2018 yılında iBBS 1 düzeyinde (12 bölgede) bölgeler arasındaki göç hareketleri incelendiğinde (bkz. Tablo 1), 7 bölgede net göçün pozitif olduğu görülmektedir. Yani bölgenin aldığı göç verdiği göçten daha fazladır. Bu durumda genel olarak değerlendirildiğinde, doğu bölgelerinden batı bölgelerine doğru iç göç hareketi mevcut olmakta, bu da, Türkiye'de bölgeler arasındaki gelişmişlik farklılıklarının veya eşitsizliklerin göçün yönünü belirleyen önemli bir unsur olabileceğini göstermektedir (Akseki ve Türkcan, 2016: 1873). Bölgeler arasındaki farklılıklar incelendiğinde, az gelişmiş bölgelerden gelişmiş bölgelere doğru bir göç hareketi izlenmektedir. Tablo 1'de 
göze çarpan bir başka göç hareketi, en çok göç alan İstanbul'un 2018 yılında net göç hızının negatif olmasıdır. İstanbul'un göç alan değil, göç veren bir şehir olma konumuna geldiği dikkat çekmektedir.

Tablo 1. 2018 Yılında İBBS 1 Düzeyinde Bölgeler Arasındaki Göç Bilgileri

\begin{tabular}{lccc}
\hline & Aldığı Göç & Verdiği Göç & Net Göç \\
\hline istanbul-TR1 & 385482 & 595803 & -210321 \\
Batı Marmara-TR2 & 151786 & 111465 & 40321 \\
Ege-TR3 & 260130 & 212197 & 47933 \\
Doğu Marmara-TR4 & 250332 & 230166 & 20166 \\
Batı Anadolu-TR5 & 233228 & 270535 & -37307 \\
Akdeniz-TR6 & 251196 & 255789 & -4593 \\
Orta Anadolu-TR7 & 163406 & 130770 & 32636 \\
Batı Karadeniz-TR8 & 251795 & 182642 & 69153 \\
Doğu Karadeniz-TR9 & 194120 & 112325 & 81795 \\
Kuzeydoğu Anadolu-TRA & 100478 & 111015 & -10537 \\
Ortadoğu Anadolu-TRB & 143841 & 140005 & 3836 \\
Güneydoğu Anadolu-TRC & 182820 & 215902 & -33082 \\
\hline
\end{tabular}

Kaynak: TÜiK, Bölgesel İstatistikler, 2018.

\section{3. İç Göçün Nedenleri}

Geçmişten günümüze kadar birçok ülke için toplumsal sorun haline gelmiş olan iç göç, bireyler, toplumlar, ülkeler açısından birbirinden farklı nedenler ile ortaya çıkmaktadır (Özdemir, 2018: 1338). İç göçün nedenlerini açıklamaya geçmeden önce göç yaklaşımlarından bahsetmekte fayda vardır. Literatürde göç olgusu üç temel yaklaşım kullanılarak değerlendirilmektedir. Bunlar; fayda-maliyet yaklaşımı, itici ve çekici güçler yaklaşımı ve seçkinlik yaklaşımıdır. Fayda-maliyet yaklaşımı, bireylerin göç kararını fayda ve maliyetlere bağlı olarak verdiğini öne sürmektedir. Bu yaklaşımda göç beşeri sermaye yatırımı olarak ele alınmakta ve daha iyi bir kazanç elde etmek için bireylerin göç etmesi, eğitim gibi bir beşeri sermaye yatırımı olarak görülmektedir (Bahar ve Bingöl, 2010: 46). Bireyler bulundukları yerin olumsuz özellikleri ile gideceği yerin olumlu özelliklerini karşılaştırmaktadırlar. Göç edilmesi muhtemel tüm potansiyel bölgelerde elde edilmesi beklenen getirinin bugünkü değerini ve göç etmenin maliyetini yani beşeri sermaye yatırımını hesaplamaktadırlar. Eğer göç ile beklenen fayda yani göç etmenin beklenen getirisi, göç etmenin maliyeti çıkarıldıktan sonra göç etmeme durumunda elde edilecek beklenen getiriden yani bulunduğu yerde kalmanın getireceği maliyetten yüksek ise bireyler göç kararını vermektedir (Bahar ve Bingöl, 2010: 46; Çetin ve Çetin, 2018: 101). Burada göç etmenin maliyetinden kasıt sadece seyahat masrafları veya göç edilen bölgede yaşamanın maliyeti değil, aynı zamanda aile ve arkadaşlardan ayrılma gibi psikolojik maliyetlerdir. Faydamaliyet yaklaşımında getiri ve maliyetler her birey tarafından, bireyin yaş, cinsiyet, eğitim düzeyi gibi özellikleri dikkate alınarak farklı hesaplanmaktadır (Çetin ve Çetin, 2018: 101).

İtici ve çekici güçler yaklaşımı, göç edilen bölgelerde (kaynak bölgelerde) iticiliğe, göç edilecek bölgelerde çekiciliğe neden olan faktörleri ele almaktadır. Bu yaklaşımın temelini oluşturan E. G. Ravenstein'ın $(1885,1889)$ "Göç Kanunları" adlı çalışmalarına göre bireyler ekonomik fırsatların az olduğu yerlerden çok olduğu yerlere doğru göç ederler. Ravenstein'ın önermelerini güncelleyen Lee (1969), göç kararını etkileyen esas faktörleri tespit etmeye çalışmış ve göçü etkileyen unsurları "itici ve çekici faktörler" olarak iki gruba ayırmıştır (Bahar ve Bingöl, 2010: 47; Sevinç vd., 2018: 75). Kişilerin yaşadıkları ortamı ve alışkın oldukları yaşam tarzını bırakarak göç etmelerine neden olan faktörlere "itici faktörler", göç edecekleri yerin cezbeden özelliklerine ise "çekici faktörler" adı verilmektedir (Bülbül ve Köse, 2010: 78). İtici ve çekici faktörlerin neler olduğu ilerleyen kısımda açıklanacaktır.

Seçkinlik yaklaşımı, eğitim, yaş, cinsiyet, medeni durum gibi demografik faktörler ve sosyal faktörler dikkate alındı̆ı̆ında göç eden bireylerin, göç etmeyenlere göre seçkin oldukları tezine dayanmaktadır. Seçkinlik yaklaşımını ortaya koyanlar ve geliştirenler Dorothy Thomas (1938) ve Simon Kuznets (1964)'dir. 
Kuznets göç eden bireylerin sosyal ve demografik özelliklerine göre seçkin olduğunu belirtir (Bahar ve Bingöl, 2010: 47).

İç göçün nedenlerini veya belirleyicilerini dört ana başlıkta toplamak mümkündür. Bunlar ekonomik, siyasi, sosyo-kültürel belirleyiciler ve nüfus artışıdır. İç göçün Türkiye'de bilinen nedenleri "itici", "çekici" ve "iletici" nedenler olarak sınıflandırılabilir. İtici faktörler, bireylerin doğdukları ve alışkın oldukları kırsal yaşam tarzını bırakarak göç kararı almasına neden olan faktörlerdir. Kırsal alanda sanayileşme ile birlikte yaşanan gelişmeler, tarım kesiminde devlet desteklerinin azaltılması, tarımsal KiT'lerin özelleştirilmesi, tarımda makineleşme, toprak yetersizliği ve toprakların miras yoluyla parçalanması, entansif tarıma geçiş, yüksek doğurganlık ve hızlı nüfus artışı, istihdam olanaklarının kısıtlı olması, göç edenlerin yaşadıkları bölgedeki yüksek işsizlik oranları, gelir darlığı, gelir dağılımındaki çarpıklık ve buna bağlı olarak ortaya çıkan yoksulluk, sosyal dengesizlikler, coğrafi ve doğal koşulların yetersizliği, iklimdeki küresel etki, doğal afetler, terör, kan davaları, mezhepsel çatışmalar gibi güvenlik unsurları ve geniş aile yapısı itici faktörleri oluşturmaktadır. Çekici faktörler, göç etmek üzere karar verilen yerin cazibeleridir. İstihdam ve gelir olanakları, kentsel yaşamın getirdiği refah ortamı, gelecek kuşaklarına yaşanılabilir daha iyi bir gelecek sunma, göç edilen bölgenin coğrafi konumu, kentlerdeki toplumsal ve kültürel olanaklardan yararlanma, yüksek hayat standardı, kaliteli eğitim, sosyal hizmetlerin fazla olması ve sağlık hizmetlerinden yararlanma isteği çekici faktörleri oluşturmaktadır (Bahar ve Bingöl, 2010: 47; Aşkın vd., 2013: 233; Sevinç vd., 2014: 399; Albayrak ve Abdioğlu, 2017: 294; Temel, 2017: 34; Çetin ve Çetin, 2018: 99). Burada itici ve çekici faktörlere fiziksel maliyetleri temsil eden uzaklık ve ayrıca parasal olmayan siyasi, dini veya etnik bazı sınırlamaları içeren "engeller" de dahil edilmektedir (Bindak, 2015: 112). Haberleşme, iletişim ve ulaşım olanak ve teknolojilerinin yaygınlık kazanması, bu teknolojilerdeki hızlı gelişmelerle birlikte mal ve hizmet piyasalarının belli odaklarda toplanması iletici faktörleri oluşturmaktadır (Şen, 2014: 238; Anavatan, 2017: 1110; Sevinç vd., 2018: 76). Bu sayılanlar dışında evlilik, boşanma, iş değişikliği/tayin, emeklilik, ebeveynin göç etmesi gibi nedenler de bulunmaktadır. Ayrıca hem göç alan hem de göç veren bölgelerdeki konut yetersizliği de iç göçlere neden olmaktadır (Tuncer ve Kalay, 2016: 169).

Türkiye'deki göç hareketleri sosyo-ekonomik olaylardan bağımsız olmayıp tam tersi, ekonomideki yapısal değişimleri en iyi yansıtan göstergelerden birisi olma özelliğine sahiptir (Manavgat ve Saygılı, 2016: 3). Göç olgusu basit bir yer değişikliği süreci gibi görünse de neden ve sonuçları itibarıyla toplumlarda ve bireylerde çok önemli etkiler yaratmaktadır (Temel, 2017: 5).

\section{Literatür Taraması}

Çalışmanın bu bölümünde Türkiye'de iç göçün belirleyicilerinin ampirik olarak araştırıldığı çalışmalar üzerinde durulmaktadır. Bu çalışmalardan bazıları şunlardır:

Topbaş (2007), Türkiye' de iç göç üzerinde etkili olan faktörleri 2000 yılı Genel Nüfus Sayımı verilerini kullanarak, yatay kesit ve logit regresyon analizleriyle il düzeyinde belirlemeye çalışmıştır. Kamu yatırımlarını, göç stokunu, uzaklığı, işsizliği ve kişi başına geliri iç göçün belirleyicileri olarak tespit etmiştir. Pazarlıoğlu (2007), İzmir'de iç göçe etki eden faktörleri 2002 yılında yapılan anket verilerini kullanarak iki değişkenli probit model yardımıyla belirlemeye çalışmıştır. Bireylerin yaşını, eğitim düzeyini, çalıştığı sektör ve mesleği ile uzaklık değişkenlerini modele dahil etmiştir. İç göçü belirleyen değişkenlerin yaş, eğitim, uzaklık, bireylerin imalat ve hizmet sektöründe çalışması olduğunu ifade etmiştir. Ercilasun, Hiç Gencer ve Ersin (2011), 2010 yılında Türkiye'de iç göçleri etkileyen faktörleri iller bazında en küçük kareler yöntemi ile belirlemeye çalışmışlardır. Başka ilde doğanların ikamet ettiği ilin toplam nüfusa oranı, sağlık sektörü gelişmişlik endeksi, eğitim sektörü gelişmişlik endeksi, sosyo-ekonomik gelişmişlik endeksi, şehirleşme oranı, TÜFE, kişi başına GSYiH, reel ücret ortalaması, çalışabilir nüfus, işsizlik oranı ve üniversitede okuyan toplam öğrenci sayısı değişkenlerini almışlardır. İç göç üzerinde etkili olan en önemli faktörün, bir yere daha önceden göç etmiş olanların çekici gücü olduğu bulgusunu elde etmişlerdir. Ayrıca göç kararının illerdeki üniversitelerin kapasitesinin yüksekliğine bağı olduğunu belirtmişlerdir. Yakar (2012), Türkiye'de iç göçün mekânsal dağılımını 1995-2000 dönemi için mekânsal analizleri kullanarak incelemiştir. i̇ç göçün ilçelerin karakteristiklerine (az gelişmiş/gelişmiş, kırsal/kentsel, doğu/batı, denize yakın/denizden uzak) göre değiştiği bulgusuna ulaşmıştır. Abar (2014), 2008-2012 döneminde Türkiye'de il bazında iç göç hareketlerini mekânsal 
panel veri analiziyle incelemiştir. Stok göç, illerin sosyo-ekonomik gelişmişlik düzeyleri ve iller arası mesafeyi bağımsız değişkenler olarak kullanmıştır. iller arası göç üzerinde sosyal ağların etkili olduğu, mesafenin göçü azalttığı, göç hareketlerinin az gelişmiş bölgelerden gelişmiş bölgelere doğru olduğu ve iç göçün mekânsal etkiler içerdiği sonucunu elde etmiştir. Doğan ve Kabadayı (2015), Türkiye'de iç göç üzerinde etkili olan faktörleri 2008-2012 döneminde panel veri analizi ile belirlemeye çalışmışlardır. Analiz sonucunda iç göçe neden olan faktörlerin iş ve yüksek gelir fırsatları, eğitim, sağlık, güvenlik olduğunu tespit etmişlerdir. Karpat Çatalbaş ve Yarar (2015), Türkiye'de ỉBBS 2 düzeyinde (26 bölgede) bölgeler arası iç göçün belirleyicilerini saptadıkları çalışmalarında 2008-2012 dönemine ait verileri kullanarak panel veri analizi yapmışlardır. Bölgelerin zenginlikleri ve sanayileşmelerini temsilen vekil değişken olarak kişi başına elektrik tüketimini almışlar, aynı zamanda eğitim indeksini, istihdam oranını, enflasyon oranını, işsizlik oranını ve terörden doğrudan etkilenen iller için terör değişkenini kullanmışlardır. Bölgenin zenginlik düzeyinin göç üzerinde olumlu, enflasyon ve istihdam oranı ile yaşanan terör olaylarının ise olumsuz etkisi olduğu bulgusuna ulaşmışlardır. Sigeze ve Ballı (2016), Türkiye'de 12 bölgeyi kapsayan iBBS 1 düzeyinde 2008-2014 yılları arasında iç göçün belirleyicilerini Uygulanabilir Genelleştirilmiş En Küçük Kareler (Feasible Generalized Least Squares) yöntemiyle tespit etmeye çalışmışlardır. Bölgelerin gelişmişlik düzeyi için kişi başına ihracat miktarını ve kişi başına elektrik tüketimini vekil değişken olarak kullanmışlardır. Bunlar dışında yoksulluk oranı, işsizlik oranı, lisede okuyan öğrenci sayısı ve terör değişkenlerini ele almışlardır. Yoksulluk değişkeninin katsayısını negatif işaretli olarak bulmuşlardır. İhracat ve kişi başına elektrik tüketiminin bölgenin net göç oranı üzerinde anlamlı ve pozitif etkili olduğunu saptamışlardır. Yayar, Uçgunoğlu ve Demir (2016), iller arasındaki net göç hızını etkileyen faktörleri belirlemeyi amaçlamışlardır. Bunun için 2014 yılına ait yatay kesit verilerini kullanarak çoklu doğrusal regresyon analizi uygulamışlardır. İşsizlik oranı, doktor sayısı, okur-yazar nüfus oranı, yoksulluk oranı, nüfus artış hızı ve ilin bulunduğu bölge için yedi tane bölge kukla değişkenini analize dahil etmişlerdir. Model sonuçları, net göç hızı üzerinde işsizlik oranının negatif, okur-yazar nüfus oranının ve nüfus artış hızının pozitif etkili olduğunu göstermiştir. Doğu Anadolu Bölgesi'ne göre ilin diğer bölgelerde yer almasının net göçü artırdığı bulgusuna ulaşmışlardır. Manavgat ve Saygılı (2016), Türkiye'nin 26 alt bölgesinde 2008-2011 yılları arasında göç hareketlerinde itici ve çekici faktörlerin etkisini mekânsal panel veri modelleriyle analiz etmişlerdir. Kullanılan değişkenler gelir farkı, işsizlik oranı, organik tarım ve tarım alanı ile trafiktir. Net göç alan ve veren bölgelerde mekânsal yayılma etkisinin olduğunu ifade etmişlerdir. Göç veren bölgelerin düşük gelir düzeyine sahip olmasının, göç alan bölgelerin yüksek gelir düzeyine sahip olmasına göre daha güçlü etki gösterdiği sonucuna ulaşmışlardır. Bölgenin gelir farkının ve işsizliğin artması ile tarım alanlarının azalmasının göç üzerinde anlamlı bir etkiye sahip olduğunu bulmuşlardır. Tatı (2016), 2014 yılında Türkiye'de iller bazında göçü etkileyen faktörleri belirlemek için mekânsal ekonometrik analizler gerçekleştirmiştir. Evlenme hızı, boşanma hızı, doğum sayısı, tarım alanı, bal üretimi, üniversite mezunu sayısı ve üniversite sayısı değişkenlerini kullanmıştır. Her bir lokasyon için verilen göç oranının söz konusu değişkenlerden etkilendiğini ayrıca, bir bölgede verilen göç oranının düşük ya da yüksek olmasının, kendisine komşu olan bölgelerin de verilen göç oranlarını etkilediğini belirtmiştir. Yerdelen Tatoğlu (2017), Türkiye'de IBBS 1 düzeyinde yer alan 12 bölgede 2008-2014 döneminde net göç hızının belirleyicilerini sıralı panel logit regresyon analizi ile incelemiştir. Üniversite sayısı, sinema salonu sayısı, nüfus artış hızı, boşanma oranı, evlenme oranı, traktör sayısı, inen ve kalkan uçak sayısı değişkenlerini kullanmıştır. Bölgedeki üniversite sayısı, traktör sayısı, inen ve kalkan uçak sayısı ve evlenme oranı değişkenlerinin net göç oranını azalttığı, sinema salonu sayısı, nüfus artış hızı ve boşanma oranı değişkenlerinin arttırdığı sonucunu elde etmiştir.

\section{Ampirik Analiz}

\subsection{Model ve Veri Seti}

Çalışmada, Türkiye'de iç göçü etkileyen faktörleri analiz etmek amacıyla, 2008-2017 yılları kapsamında İBBS Düzey 1 bölgeleri (12 alt bölge) için mekânsal panel veri analizi kullanılmıştır. Çalışmanın 2008-2017 dönemlerini kapsamasının nedeni, çalışmada kullanılan verilerin güncel ve ortak olarak bu dönem için bulunabilir olmasıdır. İçgöçü etkileyen unsurlar incelenir iken, çalışma kapsamını oluşturan bölgeler göç alan ve göç veren şeklinde ikiye ayrılmıştır. Bu şekilde iç göçü etkileyen faktörler hem göç alan bölgeler hem de göç veren bölgeler için ayrı ayrı yorumlanabilecektir (Topbaş, 2007; Manavgat ve Saygılı, 2016; Tatlı, 2016; Tatoğlu, 2017). Bu açıdan bir bölgenin aldığı göç toplamı verdiği göç toplamından fazla ise göç alan; eksik ise 
göç veren bölge olarak belirlenmektedir. Bu kapsamda 2008-2017 yılları arasında göç veren 7 ve göç alan 5 bölge belirlenmiştir. ${ }^{1}$ Bu çalışmada Türkiye için Düzey 1 bölgelerinde, iç göçü belirlemede etkili olan değişkenler için sırasıyla göç alan ve göç veren bölgeler için oluşturulan modeller incelenmiştir. Çalışmanın modeli, Abar (2004), Karpat ve Yarar (2015), Manavgat ve Saygılı (2016) ve Anavatan (2017) çalışmalarından esinlenerek oluşturulmuştur. Çalışma kapsamında iç göçü etkileyen sosyo-ekonomik değişkenlere yer verilmiştir. Çalışmada değişkenlerin logaritmik değerleri kullanıımıştır.

$$
\begin{aligned}
& \quad L G A_{i t}=\beta_{0}+\beta_{1} L \dot{\mathrm{I}} S_{i t}+\beta_{2} L U M_{i t}+\beta_{3} L \dot{\mathrm{I}} H R_{i t}+\beta_{4} L K B G S Y \dot{\mathrm{I}} H_{i t}+\beta_{5} L H Y S_{i t}+\beta_{6} L T A_{i t}+ \\
& \varepsilon_{i t} \\
& \mathrm{i}=1, \ldots, \mathrm{N} \quad \mathrm{N}=5 \\
& \mathrm{t}=1, \ldots, \mathrm{T} \quad \mathrm{T}=10 \\
& L V A_{i t}=\alpha_{0}+\alpha_{1} L \dot{\mathrm{I}} S_{i t}+\alpha_{2} L O B_{i t}+\alpha_{3} L \dot{\mathrm{I}} T H_{i t}+\alpha_{4} L K B G S Y \dot{\mathrm{I}} H_{i t}+\alpha_{5} L H Y S_{i t}+\alpha_{6} L T A_{i t}+ \\
& \omega_{i t} \\
& \mathrm{i}=1, \ldots, \mathrm{N} \quad \mathrm{N}=7 \\
& \mathrm{t}=1, \ldots, \mathrm{T} \quad \mathrm{T}=10
\end{aligned}
$$

Model 1 ve 2'de yer alan bağımlı değişkenler $G_{i t}$ ve $V A_{i t} t$ zammında "i" bölgesinin aldığı ve verdiği göçü ifade etmektedir. Veriler TÜiK' den alınmıştır. Modeli açıklayan değişkenlerden olan istihdam sayısı (IS) ve işsizlik sayısı (iş̧) değişkenleri, göç alan ve göç veren bölgelerdeki istihdam edilen ve işsiz olan kişi sayısını göstermektedir. İktisadi olarak istihdam sayısının arttı̆̆ı bölgelerde iş olanakları fazlalaştığından dolayı göç alması beklenir. Bu sebeple $\beta_{1}$ ve $\alpha_{1}$ katsayılarının göç alan ve göç bölgeler için pozitif olması beklenmektedir. Bir diğer değişken grubu eğitim alanından elde edilen üniversite mezun sayısı (UM) ve bir okul bitirmeyen kişi sayısıdır (OB). Bir bölgede üniversite mezun sayısının yüksek olması eğitim seviyesinin yüksek olduğunu ve ayrıca işgücünün nitelikli ve kalifiyeli olduğunu göstermektedir. Bununla birlikte, bir bölgede herhangi bir okul bitirmeyen kişi sayısının fazlalığı eğitim seviyesinin düşüklüğü ve aynı zamanda işgücünde meydana gelebilecek olumsuz şartların fazla yaşanabileceğini göstermektedir. Bu doğrultuda $\beta_{2}$ ve $\alpha_{2}$ katsayılarının göç alan ve göç veren bölgeler için pozitif olması beklenmektedir. Gelir kalemini oluşturan diğer iki önemli değişken ihracat (iHR) ve ithalattır (ITH). Göç alan bölgelerin bir diğer önemli özelliği ekonomik koşulların ve üretim-tüketim şartlarının diğer bölgelere göre daha avantajlı olmasıdır. Bu sebeple göç alan bölgelerin üretim değerlerinin yüksek olması göç veren bölgelerin ise tüketim değerlerinin yüksek olması beklenmektedir. Bu nedenle $\beta_{3}$ ve $\alpha_{3}$ katsayılarının göç alan ve göç veren bölgeler için pozitif olması beklenmektedir. Bir diğer ekonomik değişken kişi başına düşen gayri safi yurt içi hâsıladır. Bir bölgenin önemli gelişmişlik düzeylerinden biri kişi başına düşen gayri safi yurt içi hâsılanın yüksekliğidir. Bu anlamda hem üretim hem de üretimin gelire dönüşmesi bölgede yaşayan insanların refah düzeylerini arttırmalarını sağlayacaktır. Bu açıdan düşünüldüŭünde $\beta_{4}{ }^{\prime}$ ün göç alan bölge için pozitif, $\alpha_{4}{ }^{\prime}$ ün göç veren bölge için negatif etkide bulunması beklenilmektedir. Sağlık açısından ele alınan bir diğer önemli değişken hastane yatak sayısıdır (HYS). Özellikle sağlık anlamında gelişme göstermiş bölgelerin önemli özelliği hastane sayısı ve hastane yatak sayısının fazlalı̆ıdır. Kırsal bölgeden kentsel bölgeye meydana gelen göçün önemli nedenlerinden birisi de yeterli sağlık hizmeti alınamamasıdır. Bu anlamda $\beta_{5}$ katsayısı göç alan bölgeler için pozitif etkiye sahip olması beklenirken, $\alpha_{5}$ açısından hastane yatak sayısındaki azalış göç veren bölgeleri olumsuz etkileyecektir. Çalışmaya ilişkin son açıklayııı değiş̧en tarım alanıdır (TA). Türkiye'de göç alan bölgelere ilişkin tarım faaliyetlerinin gerçekleştiği üretim alanları oldukça büyük bir paya sahiptir. Özellikle son dönemde organik tarımın önemli hale gelmesi, kırsal bölgelerde bu alanların daha kısıtlı olması nedeniyle tarım nüfusu alanlarının yaygın olduğu bölgelere hareket etmektedir. Dolayısıyla bu durum göç alan bölgelerin göç almasında önemli bir etken olabileceği düşüncesiyle tahmini $\beta_{6}$ katsayısı pozitif olmalıdır. Göç veren bölgede ise kırsal alanların yaygınlığı ve tarımın sürdürülebilir kalkınmada önemli rol oynaması, bu bölgelerde tarım arazilerine duyulan ihtiyacı artırmaktadır. İşlenmiş tarım alanlarının yüksek olması kırsal bölgelerin göçü üzerinde engelleyici bir faktör olarak ele alınabileceğinden tahmini $\alpha_{6}$ katsayısına ilişkin işaret beklentisi ise negatiftir. 


\subsection{Yöntem}

Mekânsal ekonometrinin klasik ekonometriden en önemli ayrımı, gözlemler arasında mekânsal bağıntının olması ve oluşturulan modellerde mekânsal heterojenliğin olmasıdır. Bu sebeple mekânsal heterojenliğinin boyutunun önemli derecede olduğu ya da coğrafi konumundan dolayı birimler birbirleriyle etkileşim halindeyse mekânsal bağımlılı̆ının tespiti belirlenmelidir. Buna bağlı olarak da mekânsal ekonometrik modellerin kullanılması gerekmektedir (Anselin, 1998: 18).

Mekânsal ekonometride veri seti gerek yatay kesit gerekse de panel veri seti olsa da mekânsal komşuluk ağırlık matrisleri(W) ile tanımlanır. Birimlerin mekânsal yakınlığına bağlı olarak hesaplanan ağılık matrisi W, nxn boyutlu sınır ya da uzaklık ilişkisini göstermektedir. Mekânsal bağımlıık analize gecikme operatörü ile dâhil edilir (Çetin, 2012: 70).

$$
W y_{i}=\sum_{j=1}^{N} w_{i j} y_{j}
$$

Eşitlik 3'te W pozitif ve simetrik ağırlık matrisidir, y gözleminin komşusunu baz alarak ilişkilendirilmesinde kullanılır ve böylece gecikme operatörü oluşturulur. Mekânsal ekonometride bağımlılığı içeren iki tür model vardır.

Mekânsal Gecikme Modeli (SAR) bunlardan ilkidir. Coğrafi bağımlılık taşıyan birimlere ait y bağımlı değişkeni üzerinde komşuluk içeren y değişkenlerinin de etkisi olduğunu varsayar. Bu modelin gösterimi şu şekildedir:

$$
\begin{aligned}
& y=\rho W_{y}+X \beta+\varepsilon \\
& \varepsilon \sim N\left(0, \sigma^{2} I\right)
\end{aligned}
$$

Modelde yer alan mekânsal bağıntının değeri $(\rho)$ ve mekânsal ilişkiye sahip gözlemler arasındaki bağıntıya dayalı olan ağırlık matrisi de W'dir.

Mekansal Hata Modeli (SEM) ise mekansal bağımlılığı içeren ikinci modeldir. Ekonometrik modelin hata terimlerinde mevcut olan otoregresif yapıyı incelemektedir. Bu modelin gösterimi aşağıdaki gibidir:

$$
\begin{aligned}
& y=X \beta+\varepsilon \\
& \varepsilon=\lambda W \varepsilon+u \\
& u \sim N\left(0, \sigma^{2} I\right)
\end{aligned}
$$

$\lambda$ hata terimlerine ilişkin mekânsal bağımlılı̆ı̆n ölçüsüdür (Anselin, 1998: 100).

Çalışmada mekânsal panel veri analizi uygulandığından ele alınan modellerin panel şeklinde genişletmek mümkündür. Panel veri analizde seriler hem kesit hem de zaman boyutunda oluşturulmaktadır. Panel veri analizinin içerdiği varsayımlara göre havuzlanmış, sabit etkiler ve rassal etkiler modeli olmak üzere üç farklı şekilde tahmin edilmektedir.

Havuzlanmış modelde kesitler arasındaki heterojenlik dikkate alınmaz. Bu modele ilişkin eşitlik 1'de yer alan denkleme mekânsal etkileşim dahil edilerek aşağıdaki şekilde gösterilmiştir.

Havuzlanmış Mekânsal Gecikme Modeli (PSAR)

$$
\begin{aligned}
& L G A_{i t}=\theta+\rho w L G A_{i t}+\beta_{1} L \dot{\mathrm{I}} S_{i t}+\beta_{2} L U M_{i t}+\beta_{3} L \dot{\mathrm{I}} H R_{i t}+\beta_{4} L K B G S Y \dot{\mathrm{I}} H_{i t}+\beta_{5} L H Y S_{i t}+ \\
& \beta_{6} L T A_{i t}+\varepsilon_{i t} \\
& \varepsilon_{i t} \sim N\left(0, \sigma^{2} I\right)
\end{aligned}
$$


Havuzlanmış Mekânsal Hata Modeli (PSEM)

$$
\begin{aligned}
& L G A_{i t}=\theta+\beta_{1} L \dot{I} S_{i t}+\beta_{2} L U M_{i t}+\beta_{3} L \dot{I} H R_{i t}+\beta_{4} L K B G S Y \dot{I} H_{i t}+\beta_{5} L H Y S_{i t}+\beta_{6} L T A_{i t}+ \\
& \varepsilon_{i t} \\
& \varepsilon_{i t}=\lambda W \varepsilon_{i t}+u_{i t} \\
& u_{i t} \sim N\left(0, \sigma^{2} I\right)
\end{aligned}
$$

Aynı model kalıpları eşitlik 2 için de kurulabilir.

Sabit Etkiler modelinde ise, kesitler arası heterojenliğin varsayımıyla, her bir kesite ilişkin sabit terim eklenerek birimler arası oluşacak farklılıklar belirlenir. $\varphi_{i}^{\prime}$ de kesitler arası gözlemlenemeyen etkiyi ortaya koymaktadır. Bu modele ilişkin mekânsal etkileşim dahil edildiği modeller yine eşitlik 1 yardımıyla aşağıda gösterilmiştir.

Sabit Etkiler Mekânsal Gecikme Modeli (FSAR)

$L G A_{i t}=\phi_{i}+\rho w L G A_{i t}+\beta_{1} L \dot{\mathrm{I}} S_{i t}+\beta_{2} L U M_{i t}+\beta_{3} L \dot{\mathrm{I}} H R_{i t}+\beta_{4} L K B G S Y \dot{\mathrm{I}} H_{i t}+\beta_{5} L H Y S_{i t}+$ $\beta_{6} L T A_{i t}+\varepsilon_{i t}$

$\varepsilon_{i t} \sim N\left(0, \sigma^{2} I\right)$

Sabit Etkiler Mekânsal Hata Modeli (FSEM)

$$
\begin{aligned}
& L G A_{i t}=\phi_{i}+\beta_{1} L \dot{I} S_{i t}+\beta_{2} L U M_{i t}+\beta_{3} L \dot{I} H R_{i t}+\beta_{4} L K B G S Y \dot{I} H_{i t}+\beta_{5} L H Y S_{i t}+\beta_{6} L T A_{i t}+ \\
& \varepsilon_{i t} \\
& \varepsilon_{i t}=\lambda W \varepsilon_{i t}+u_{i t} \\
& u_{i t} \sim N\left(0, \sigma^{2} I\right)
\end{aligned}
$$

Rassal Etkiler modelinde ise, yatay kesit birimlerinde veya birimler ve zamana göre meydana gelen değişmeler hata teriminin bir bileşeni olarak modelde yer almaktadır. Mekânsal etkileşimin dâhil edildiği rassal etkiler modeli tahmincilerine eşitlik 1 yardımı ile aşağıda yer verilmiştir.

Rassal Etkiler Mekânsal Gecikme Modeli (RSAR)

$$
\begin{aligned}
& L G A_{i t}=\rho w L G A_{i t}+\beta_{1} L \dot{\mathrm{I}} S_{i t}+\beta_{2} L U M_{i t}+\beta_{3} L \dot{\mathrm{I}} H R_{i t}+\beta_{4} L K B G S Y \dot{\mathrm{I}} H_{i t}+\beta_{5} L H Y S_{i t}+ \\
& \beta_{6} L T A_{i t}+\tau_{i t}+\varepsilon_{i t} \\
& \tau_{i t}=\sigma_{N}^{2} / \sigma^{2} \\
& \varepsilon_{i t} \sim N\left(0, \sigma^{2} I\right)
\end{aligned}
$$

Rassal Etkiler Mekânsal Hata Modeli (RSEM)

$$
\begin{aligned}
& L G A_{i t}=\beta_{1} L \dot{I} S_{i t}+\beta_{2} L U M_{i t}+\beta_{3} L \dot{I} H R_{i t}+\beta_{4} L K B G S Y \dot{I} H_{i t}+\beta_{5} L H Y S_{i t}+\beta_{6} L T A_{i t}+\tau_{i t}+ \\
& \varepsilon_{i t} \\
& \varepsilon_{i t}=\lambda W \varepsilon_{i t}+u_{i t} \\
& u_{i t} \sim N\left(0, \sigma^{2} I\right)
\end{aligned}
$$

Mekânsal panel modellerinden sonraki aşamada önemli olan hangi modelin en uygun tahminci olduğudur. Bunu belirlemek için bazı model belirleme testlerinin uygulanması gerekmektedir. Bu testlerden ilki Moran I testidir. Mekânsal ardışık bağıntıya istinaden gerçekleştirilen bu sınamada alternatif hipotezde yer alan mekânsal korelasyonun içeriği net değildir. Bu sebeple sadece mekânsal ardışık bağıntının var olup olmadığı araştıııır. Hata terimlerinin dağılımının normal olduğu varsayımı altında yapılan Moran I istatistiği şu şekilde hesaplanmaktadır: 
$I=\frac{N}{S_{0}}\left(\frac{e^{\prime} W e}{e^{\prime} e}\right)$

Eşitlikte N gözlem sayısını, So ise mekânsal ağılık matrisine ait birimlerin toplamını temsil etmektedir. Moran I istatistik değerinin +1 değerine yakınsaması pozitif -1 değerine yakınsaması ise negatif güçlü mekânsal bağımlılı̆̆ göstermektedir. Bu değer 0 ise mekânsal bağımlıı̆̆ının olmadığı sonucuna ulaşılır.

Model belirleme testlerinden bir diğeri ise Lagrange çarpan testidir. Moran I test istatistiğinin tersine Maksimum Olabilirlik Metodu'na dayalı sınamalar alternatif hipotezlere dayanarak oluşturulur. Mekânsal gecikme modeli dair hipotezlere aşağıda yer verilmiştir. Aynı hipotez $\lambda$ katsayısına ilişkin mekânsal hata modeli içinde yazılabilir.

$\mathrm{H}_{0:} \rho=0$ (mekânsal gecikme yoktur)

$H_{a}: \rho \neq 0$ (mekânsal gecikme vardır)

Mekânsal Hata Modeli ve Mekânsal Gecikmeli Model için oluşturulan Lagrange Çarpanı Test istatistikleri ( $\left(M_{E R R}\right.$ ve $\left.L M_{L A G}\right)$ şu şekilde elde edilmektedir (Anselin ve Florax, 1995: 5).

$$
L M_{E R R}=L M_{\lambda}=\left(e^{\prime} W e / \sigma^{2}\right)^{2} / \operatorname{tr}\left(W^{\prime} W+W^{2}\right)
$$

$\sigma^{2}=e^{\prime} e / n$ olarak tanımlanmıştır. Bu sınama istatistiği $\chi^{2}$ dağılımı gösterir ve serbestlik derecesi 1'dir.

$$
L M_{L A G}=L M_{\rho}=\left\{e^{\prime} W y / \sigma^{2}\right\} /\left\{(W x b)^{\prime} M W x b / \sigma^{2}+\operatorname{tr}\left(W^{\prime} W+W^{2}\right)\right\}
$$

Burada $M=I-x\left(x^{\prime} x\right)^{-1} x^{\prime}$ dir. Bu istatistik de $\chi^{2}$ dağılımı gösterir ve serbestlik derecesi 1'dir.

$\mathrm{Bu}$ testlerden her ikisi de anlamlı ise, robust dönüşümlerinin de uygulanıp test edilmesi gerekmektedir. Robust dönüşümler yapılarak mekânsal etkinin hangi modelden kaynaklandığı tespit edilebilmektedir ve elde edilen nihai model EKK modeli ile kıyaslanabilmektedir (Anselin, 2003:157).

\subsection{Bulgular}

Bu aşamada Türkiye'de göç alan ve göç veren bölgeler için bu durumun belirleyicileri üzerine oluşturulan modeller ışığında, mekânsal komşuluk ilişkisinin var olup olmadığına yönelik mekânsal model belirleme sınamalarına ve ardından tahmin edilen model sonuçlarına yer verilmiştir.

Çalışmada Düzey 1 bölgelerinin göç alan ve göç veren bölgelerinde iç göçü belirlemede kullanılan değişkenlerin, bölgenin göçü üzerindeki etkilerinin komşuluk ilişkileri bakımından mekânsal bağımlıık oluşturup oluşturmadığının belirlenmesine yönelik mekânsal model belirleme sınamaları gerçekleştirilmiştir. Bu açıdan gerçekleştirilen Mekânsal Hata Modeli ( $\left(M_{E R R}\right)$ ve Mekânsal Gecikmeli Model ( $\left(M_{L A G}\right)$ sınamalarının sonuçlarına Tablo 2'de yer verilmiştir.

\begin{tabular}{|c|c|c|c|}
\hline Testler & Hipotezler & Test İstatistiği & Olasılık Değeri \\
\hline \multicolumn{4}{|c|}{ Göç alan Bölgeler- Mekânsal Model Belirleme Testleri } \\
\hline \multirow[t]{2}{*}{ LMLAG } & $\mathrm{H}_{0}: \rho=0$ & 2,874 & 0,071 \\
\hline & $\mathrm{H}_{\mathrm{a}}: \rho \neq 0$ & & \\
\hline \multirow[t]{3}{*}{ LMERR } & $\mathrm{H}_{0}: \lambda=0$ & 3,075 & 0,063 \\
\hline & $\mathrm{H}_{\mathrm{a}}: \lambda \neq 0$ & & \\
\hline & Göç veren $\mathrm{B}$ & kânsal Model Be & estleri \\
\hline \multirow[t]{2}{*}{ LMLAG } & $\mathrm{H}_{0}: \rho=0$ & 3,856 & 0,048 \\
\hline & $\mathrm{H}_{\mathrm{a}}: \rho \neq 0$ & & \\
\hline LMERR & $\mathrm{H}_{0}: \lambda=0$ & 5,075 & 0,027 \\
\hline
\end{tabular}

Tablo 2. Mekânsal Bağımlılık Testi Sonuçları 
$\mathrm{H}_{\mathrm{a}}: \lambda \neq 0$

Tablo 2'ye göre göç alan ve göç veren bölgeler için hem Mekânsal Gecikmeli model hem de Mekânsal Hata modeline ilişkin hesaplanan olasılık değerleri \%10 önem düzeyinde istatistiksel olarak anlamlıdır. Bu bakımdan her iki model türünün de geçerli olduğu söylenebilir. Bu durumda aşağıdaki Tablo 3'de yer alan Robust (Dirençli) LM testi sonuçlarına bakılmalıdır.

Tablo 3. Robust Mekânsal Bağımlılık Testi Sonuçları

\begin{tabular}{|c|c|c|c|}
\hline Testler & Hipotezler & Test İstatistiği & Olasılık Değeri \\
\hline \multicolumn{4}{|c|}{ Göç alan Bölgeler- Mekânsal Model Belirleme Testleri } \\
\hline \multirow[t]{2}{*}{ RLMLAG } & $\mathrm{H}_{0}: \rho=0$ & 1,957 & 0,104 \\
\hline & $\mathrm{H}_{\mathrm{a}}: \rho \neq 0$ & & \\
\hline \multirow[t]{2}{*}{$\mathrm{RLM}_{\mathrm{ERR}}$} & $\mathrm{H}_{0}: \lambda=0$ & 2,613 & 0,084 \\
\hline & $\mathrm{H}_{\mathrm{a}}: \lambda \neq 0$ & & \\
\hline \multicolumn{4}{|c|}{ Göç veren Bölgeler- Mekânsal Model Belirleme Testleri } \\
\hline \multirow[t]{2}{*}{ RLMLAG } & $\mathrm{H}_{0}: \rho=0$ & 2,520 & 0,113 \\
\hline & $\mathrm{H}_{\mathrm{a}}: \rho \neq 0$ & & \\
\hline \multirow[t]{2}{*}{ RLMERR } & $\mathrm{H}_{0}: \lambda=0$ & 4,086 & 0,076 \\
\hline & $\mathrm{H}_{\mathrm{a}}: \lambda \neq 0$ & & \\
\hline
\end{tabular}

Tablo 3'den elde edilen sonuçlara göre, hem göç alan hem de göç veren bölgelere ilişkin olarak Robust LM $\mathrm{ERR}_{\text {R }}$ test istatistiklerinin \%10 önem düzeyinde anlamlı olduğu sonucuna ulaşılmıştır. Bu sebeple mekânsal model olarak göç alan ve göç veren bölgelere ilişkin Mekânsal Hata Modeli'nin geçerli olduğuna karar verilmiştir.

Bu aşamaya kadar her iki model içinde bölgelerin göç belirleyicileri üzerinde komşuluk ilişkisine dayalı mekânsal etkinin varlığı belirlenmiştir. Çalışmada mekânsal panel analizi uygulandığı için uygun panel modelinin elde edilmesine yönelik de sınama istatistiklerinin hesaplanması gerekmektedir.

Panel veri modellerinin varsayımları sebebiyle uygun tahmin yönteminin belirlenmesi tahmin sonuçlarının tutarlılığı ve etkin olması açısından önemlidir. Bu modellerden hangisinin çalışmada kullanılan modele uygun olduğuna karar vermek için yapılan F testi, LR testi ve Hausman testinin sonuçları aşağıdaki tabloda yer almaktadır.

Tablo 4. Modeller İçin Sabit Etkiler ve Rassal Etkiler Mekânsal Model Belirleme Testleri

\begin{tabular}{|c|c|c|}
\hline Test & Test İstatistiği Değeri & Olasılık Değeri \\
\hline \multicolumn{3}{|c|}{ Göç alan Bölgeler- Mekânsal Hata Modelinde-Uygun Panel Veri Modelleri için Testler } \\
\hline F-Testi (Sabit Etki Kısıtı) & 24,865 & 0,000 \\
\hline LR-Testi (Rassal Etki Kısıtı) & 5,732 & 0,001 \\
\hline Hausman Testi & $-4,049$ & 0,006 \\
\hline \multicolumn{3}{|c|}{ Göç veren Bölgeler- Mekânsal Hata Modelinde-Uygun Panel Veri Modelleri için Testler } \\
\hline F-Testi (Sabit Etki Kısıtı) & 16,932 & 0,000 \\
\hline LR-Testi (Rassal Etki Kısıtı) & 4,984 & 0,004 \\
\hline Hausman Testi & $-2,486$ & 0,066 \\
\hline
\end{tabular}

Tablo 4'te göç alan bölgeler için mekânsal havuzlanmış ve sabit etkiler modeli arasında yapılan $\mathrm{F}$ testi sonucunda olasılık değeri \%1 önem düzeyinde anlamlı olduğundan boş hipotez (havuzlanmış mekânsal hata modeli geçerlidir) reddedilmiştir. Yine havuzlanmış ve rassal etkiler modeli arasındaki tercihte yapılan LR-testi sonucunda olasılık değeri \%1 önem düzeyinde anlamlı olduğundan boş hipotez reddedilmiş ve havuzlanmış modelin geçerli olmadığına karar verilmiştir. Bu durumda sabit etkiler mekânsal hata ve rassal etkiler 
mekânsal hata modeli arasındaki tercih için yapılan Hausman Test istatistiği sonucu önem kazanmıştır. Elde edilen olasılık değerine göre \%1 önem düzeyinde boş hipotez (rassal etkiler mekânsal hata modeli geçerlidir) reddedilmiş ve uygun mekânsal panel veri modeli olarak Sabit Etkiler Mekânsal Hata Modelinin geçerli olduğuna karar verilmiştir.

Göç veren bölgeler için de göç alan bölgelere benzer sonuçlara ulaşıımıştır. Hausman testi sonucu \%10 önem düzeyinde reddedilmiştir. Uygun mekânsal panel veri modeli olarak Sabit Etkiler Mekânsal Hata Modelinin geçerli olduğuna karar verilmiştir.

Türkiye'nin IBBS Düzey 1'de yer alan 12 alt bölge arasında, hem göç alan hem de göç veren bölgelerde mekânsal yayılma etkisinin olduğu, bir başka ifade ile göç alan bölgelerde komşunun aldığı göçün ya da göç veren bölgelerde komşunun verdiği göçün o bölgenin göç hareketinde anlamlı bir etki yaratarak, dinamik ilişki gösterdiği saptanmıştır. Bu etkinin göç alan bölgelerde ve göç veren bölgelerde mekânsal hataya bağlı olduğu görülmüş̧ür. Analizde kullanılan panel veri modeline uygun mekânsal panel veri modelleri de belirlenmiştir. Bu doğrultuda çalışmadaki Model 1 ve Model 2 için yapılan tahmini sonuçları ise aşağıdaki tablolarda yer almaktadır.

Tablo 5'de Düzey 1 bölgelerinde göç alan 5 bölge üzerine yapılan mekânsal modellere yönelik yapılan testlerde sabit etkiler mekânsal hata modeli geçerli olmaktadır. Ayrıca tabloda mekân etkisinin göz önüne alınmadığı durumdaki tahmin sonuçları verilmiştir. Burada mekânsal etkinin göz önüne alınmadığında tahmini $\beta$ katsayılarının mekân etkisi olduğu modellere göre oldukça sapmalı olduğu tespit edilmiştir. Çünkü modeli açıklamada mekânsal etkileşim göz önüne alınmadığından tahminci katsayıları sapmalı ve model sonuçları geçerli olmamaktadır (Anselin,1988).

Tablo 5. Göç Alan Bölgeler için Tahmin Sonuçları

\begin{tabular}{|c|c|c|}
\hline Bağımlı Değişken: $L G A_{i t}$ & Sabit Etkili Mekânsal Hata Modeli & $\begin{array}{c}\text { Mekânsal Etkinin Olmadığı EKK } \\
\text { Modeli }\end{array}$ \\
\hline$\phi_{i}$ & $1,473\left[0,024^{* *}\right]$ & $2,940[0,106]$ \\
\hline İstihdam Sayısı $\left(L \dot{I} S_{i t}\right)$ & $0,382\left[0,069^{*}\right]$ & $-1,463\left[0,087^{*}\right]$ \\
\hline Üniversite Mezun Sayısı $\left(L U M_{i t}\right)$ & $-1,084\left[0,045^{* *}\right]$ & $-3,432\left[0,079^{*}\right]$ \\
\hline İhracat Miktarı $\left(L \dot{\mathrm{I}} H R_{i t}\right)$ & $0,774\left[0,091^{*}\right]$ & $1,028[0,104]$ \\
\hline $\begin{array}{l}\text { K.B. Gayri Safi Yurt İçi Hâsıla } \\
\left(L K B G S Y \dot{I} H_{i t}\right)\end{array}$ & $0,823\left[0,054^{* *}\right]$ & $0,971\left[0,076^{*}\right]$ \\
\hline Hastane Yatak Sayısı $\left(L H Y S_{i t}\right)$ & $-1,446\left[0,096^{*}\right]$ & $-5,439[0,320]$ \\
\hline Tarım Alanı $\left(L T A_{i t}\right)$ & $2,006\left[0,012^{* *}\right]$ & $-1,483[0,113]$ \\
\hline$\lambda$ (Mekânsal Bağımlılık) & $0,328\left[0,078^{*}\right]$ & - \\
\hline $\mathrm{R}^{2}$ & 0,89 & 0,67 \\
\hline Düzeltilmiş $\mathrm{R}^{2}$ & 0,87 & 0,64 \\
\hline Gözlem Sayısı & 10 & 10 \\
\hline Kesit Sayısı & 5 & 5 \\
\hline Wald Testi & $\chi^{2}=1,748$, Prob: 0,240 & $\chi^{2}=3,041$, Prob: 0,096 \\
\hline $\begin{array}{l}\text { Bhargava Düzeltilmiş Durbin } \\
\text { Watson Testi }\end{array}$ & 1,4672, Prob: 0,399 & 1,943, Prob:0,218 \\
\hline
\end{tabular}

Model 1'de göç alan bölgelerde mekânsal etkileşimin anlamlı olduğu elde edilmiştir. Bir başka deyişle, Türkiye'de göç alan Düzey 1 bölgeleri arasında pozitif mekânsal bağımlılık elde edilmiştir. Dolaysıyla göç alan bir bölgenin göç oranındaki artış, komşu bölgelere gelen göçü de artırmaktadır. Göç alan bölgelerde komşu bölgenin göç oranındaki \%1'lik artış, bölgenin göç oranında \%0,328'lik bir olumlu etki oluşturmaktadır. 
Açıklayıcı değişkenlerden istihdam sayısı değişkeninin göç alan bölge üzerindeki etkisi beklenen üzere pozitiftir. Yani Düzey 1 göç alan bölgelerdeki istihdam sayısı Türkiye'deki ortalama istihdam sayısından yüksek oldukça aldığı göç artmaktadır.

Açıklayıcı değişkenlerden üniversite mezunu sayısı değişkeni istatistiksel olarak anlamlı olsa da iktisadi olarak beklentiyi karşılamamıştır. Araştırma dönemi için artan üniversite mezun sayısının göç alan bölgeler için göç unsurunu arttırıcı bir olgu olmadığı sonucuna varılmıştır.

Göç alımı üzerinde etkili olan iktisadi değişkenlerden ihracat ve kişi başına düşen gayri safi yurt içi hâsıla değişkenlerinin katsayıları beklentilere uygun olarak pozitif bulunmuştur. Yani Düzey 1 alt bölgelerinde göç alan bölgelerdeki kişi başına düşen gayri safi yurt içi hâsıla ve ihracat miktarı Türkiye'deki ortalamadan yüksek oldukça aldığı göç attırmaktadır.

Modeldeki diğer bir değişken hastanelere ilişkin yatak sayısıdır. Özellikle kırsal ve gelişmemiş bölgelerde yeterli sağlık hizmetini alamayan nüfusun bu hizmeti alabilmek için göç edeceğini ifade etmektedir. Ancak bu değişkenin göç alan bölge üzerinde anlamlı bir etkisi gözlemlense de iktisadi olarak katsayısı negatif bulunmuştur. Bu durum bu göçün kalıcı olarak gerçekleşmediği sadece sağlık hizmeti alma şeklinde yorumlanabileceğini düşündürmüştür.

Modelde yer alan son açıklayıcı değişken, tarım alanı değişkenidir. Kırsal nüfusun tarım faaliyetlerini, geniş alanlarının bulunduğu bölgelerde sürdürmek için göç edeceğini ifade etmektedir. Bu değişken iktisadi beklentilere uygun olarak pozitif bulunmuştur. Artan tarım alanlarının göç alımını arttırdığı sonucuna ulaşılmıştır.

Elde edilen sonuçlar literatürdeki çalışmalarla karşılaşıldığında göç alan bölgeler için özellikler taşımasa da genel olarak iç göçü etkileyen unsurlar açısından bazı değişkenler için benzerlik göstermiştir. Örneğin Ercilasun, Hiç Gencer ve Ersin (2011), iç göçü pozitif yönde etkileyen faktörler olarak eğitim gelişmişlik endeksi, sağlık gelişmiş̧lik endeksi, üniversitede okuyan öğrenci sayısı ve kişi başı GSYiH'yı anlamlı bulmuşlardır. Doğan ve Kabadayı (2015) 2008-2012 yılları arasında Türkiye'de iç göçte etkili olan faktörlerin çalışmaya benzer bir şekilde eğitim ve sağılı alanlarında olduğunu tespit etmişlerdir. Sigeze ve Ballı (2016), 2008-2014 yılları için Türkiye'de bölgesel olarak ele aldıkları çalışma ile mevcut çalışmanın ortak sonucu ihracat miktarındaki artışın göçü arttırması olmuştur.

Tablo 6. Göç Veren Bölgeler için Tahmin Sonuçları

\begin{tabular}{|c|c|c|}
\hline Bağımlı Değişken: $L V A_{i t}$ & Sabit Etkili Mekânsal Hata Modeli & $\begin{array}{c}\text { Mekânsal Etkinin Olmadığı EKK } \\
\text { Modeli }\end{array}$ \\
\hline$\overline{\phi_{i}}$ & $-0,280\left[0,038^{* *}\right]$ & $-1,755\left[0,088^{*}\right]$ \\
\hline 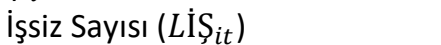 & $1,353\left[0,000^{* * *}\right]$ & $-0,886\left[0,095^{*}\right]$ \\
\hline Okul Bitirmeyen Sayısı $\left(L O B_{i t}\right)$ & $0,136\left[0,000^{* * *}\right]$ & $2,644\left[0,045^{* *}\right]$ \\
\hline İthalat Miktarı $\left(L \dot{\mathrm{I}} H T_{i t}\right)$ & $0,001\left[0,000^{* * *}\right]$ & $0,863[0,157]$ \\
\hline $\begin{array}{l}\text { K.B. Gayri Safi Yurt İ̧i Hâsıla } \\
\left(L K B G S Y \dot{I} H_{i t}\right)\end{array}$ & $-2,243\left[0,013^{* *}\right]$ & $-1,244\left[0,092^{*}\right]$ \\
\hline Hastane Yatak Sayısı $\left(L H Y S_{i t}\right)$ & $-4,170\left[0,000^{* * *}\right]$ & $2,854[0,644]$ \\
\hline Tarım Alanı $\left(L T A_{i t}\right)$ & $-0,007\left[0,000^{* * *}\right]$ & $-0,761[0,221]$ \\
\hline$\lambda$ (Mekânsal Bağımlılık) & $0,556\left[0,083^{*}\right]$ & - \\
\hline $\mathrm{R}^{2}$ & 0,94 & 0,64 \\
\hline Düzeltilmiş $\mathrm{R}^{2}$ & 0,93 & 0,62 \\
\hline Gözlem Sayısı & 10 & 10 \\
\hline Kesit Sayısı & 7 & 7 \\
\hline Wald Testi & $\chi^{2}=0,967$, Prob: 0,418 & $\chi^{2}=0,798$, Prob: 0,561 \\
\hline $\begin{array}{l}\text { Bhargava Düzeltilmiş Durbin } \\
\text { Watson Testi }\end{array}$ & 0,578, Prob: 0,506 & 0,896, Prob: 0,664 \\
\hline
\end{tabular}


Tablo 6'da Düzey 1 bölgelerinde göç veren 7 bölge üzerine mekânsal model belirlemeye yönelik yapılan testlerde mekânsal hata modeli anlamlı sonuçlar vermiştir. Model 2' de göç veren bölgeler arasında 0,55'lik bir mekân etkisinin varlığı tespit edilmiştir. Bu durum komşu bölgelerin göç verme oranı arttıkça, diğer bölgenin de göç vermesi yönünde bir etki yaratığını ortaya koymaktadır. Bir başka ifadeyle; göç veren komşu bölgede meydana gelen \%1'lik bir göç artışının, o bölgenin göçü üzerinde de olumsuz bir etki yaratarak bölgede \%0,556'lık bir göç artışına neden olduğu gözlenmektedir.

Göç veren bölgelerin göçü üzerinde etkisi olan açıklayıcı değişkenlerden kişi başına düşen gayri safi yurt içi hâsıla değişkeni göçü negatif etkilemektedir. Yani Düzey 1 alt bölgelerinde, göç veren bölgelerdeki kişi başına gelir, Türkiye ortalama kişi başına gelir düzeyine yakınlaştıkça göç verme oranı azalmaktır. Bir başka ifadeyle, Türkiye'de göç hareketinde, göç alan bölgelerdeki gelir farkının artması, göç veren bölgenin kişi başına gelirinin Türkiye ortalamasına yakınsamasından daha az oranda etkilenmektedir.

İşsiz ve bir okul bitirmeyen kişi sayısı açıklayıcı değişkenlerinin beklenti işareti olan pozitif değeri almıştır. Bu bağlamda göç veren bölgelerde işsiz ve bir okul bitirmeyen kişi sayısı arttıkça, göç edenlerin sayısında artış yaşanmaktadır.

Ekonomik açıdan değerlendirildiğinde ithalat miktarında meydana gelen bir artış bölgenin verdiği göç miktarını arttırmıştır. Bu durum iktisadi beklentileri karşılamaktadır. Üretime değil tüketime endeksli bölgelerde yaşayan insanlar zamanla iş kaygılarından ötürü ihracatın yoğun olduğu bölgelere göç etme arzusu taşırlar. Bu durum verilen göç miktarını arttırmaktadır.

Göç veren bölgede göçü etkileyen tarımsal faaliyetler açsıdan ele alınan değişken olan tarım alanı değişkeni istatistiki olarak anlamlıdır ve bölgenin verdiği göç üzerinde negatif bir etkiye sahiptir. Tarım alanlarının miktarı arttıkça göç veren bölgelerin verdiği göçte istatistiki olarak anlamlı bir azalma meydana gelmektedir.

Modele ilişkin bir diğer açıklayıcı değişken hastanelere ait yatak sayısı değişkeni ile bölgenin verdiği göç arasında istatistiki olarak anlamlı ve beklentilere uygun şekilde negatif bir ilişki saptanmıştır. Sağık açısından düşünüldüğünde artan kapasitedeki yatak sayısı bölgenin dışa verdiği göç sayısı azalmaktadır.

Elde edilen sonuçlar literatürdeki çalışmalarla karşılaşıldığında benzer sonuçlara yer vermiştir. Örneğin Yayar, Uçgunoğlu ve Demir (2016), iç göçü negatif etkileyen unsurlar adına çalışma ile ortak olarak işsizlik oranını tespit etmişlerdir. Manavgat ve Saygıı (2016), Türkiye'nin 26 alt bölgesinde 2008-2011 yılları arasında göç hareketlerinde göç alan bölgeler için işsizlik sayısının azaltıcı etkisi göç veren bölgeler için ise arttırıcı etkisi tespit edilmiştir. Yine benzer olarak tarım alanı göç alan bölgeler için pozitif etki yaparken göç veren bölgeler için ise negatif etkiye sahiptir. Bu sonuçlar çalışmanın sonuçlarıyla paralellik göstermiştir.

\section{Sonuç ve Öneriler}

Bu çalışmada, 2008-2017 yılları arasında Türkiye'de iç göçü etkileyen sosyal ve ekonomik değişkenler IBBS Düzey-1 bölgeleri için, mekânsal etkileşimi göz önünde bulunduran mekânsal panel veri modelleriyle ele alınmıştır. Bu kapsamda, çalışmada göç alan ve göç veren bölgeler tespit edilmiş ve iç göçü belirleyen, alan ve veren unsurlarla dizayn edilmiş iki mekânsal modelle test edilmiştir. Analiz sonucunda, Türkiye'de iç göç hareketlerinde mekânsal etkileşimin olduğu elde edilmiştir. Bu durum, komşu bölgenin aldığı göçün sayısı arttıkça ilgili bölgenin göçünün de artacağı benzer şekilde komşu bölgenin verdiği göç sayısı arttıkça ilgili bölgenin de göç vereceği şeklinde yorumlanabilir. Bu etkileşim aslında Türkiye'de göç olgusunun yön açısından benzer karakteristiklere sahip bölgeler arasında gerçekleştiğini göstermektedir. Bu tarz ivmenin sebebi, özellikle Türkiye'de batıdan-doğuya ve kuzeyden-güneye sosyal ve ekonomik ayrışımlara dayanmasından kaynaklanmaktadır. Dolayısıyla beklenti ve gerçekleşen göçün çoğunlukla belirli bölgelere veya belirli bölgelerden meydana geldiğidir. Bu açıdan, göç veren bölgelerde yapılacak önemli yatırımlar ve uygulanacak önemli politikalar komşu bölgeleri ve buna bağlı olarak diğer bölgeleri de olumlu yönde etkileyecektir.

Mekânsal ilişkiyle birlikte iç göçü etkileyen faktörlerin etkisi de ele alınmıştır. Göç alan bölgelere ilişkin tahmin edilen modelde, kişi başına düşen gayri safi yurt içi hâsıla değişkeninin göç alan bölgelerde alınan göçü 
artırdığı saptanmıştır. Göçü arttıran diğer değişkenler istihdam ve ihracat miktarı olmuştur. Bu açıdan bakıldığında, göç alan bölgelerde istihdam ve ihracat, Türkiye'deki ortalama istihdam ve ihracattan yüksek oldukça bu bölgelerin aldığı göçte anlamlı bir artış meydana gelmektedir. Bir diğer önemli sonuç ise göç alan bölgelerin göç almasındaki payı tarım alanları oluşturmaktadır. Özellikle kırsal alanda azalan tarım alanlarının veya tarım alanından sağlanan gelirin azalması insanları tarım alanlarından sağlanacak kazançların fazla olduğu bölgelere çekmiştir. Hastane yatak sayısı ve üniversite mezun sayısındaki artış istatistiksel olarak anlamlı olsa da göç alan bölgelerde göç sayısının azalmasına neden olmuştur. Bu durum, bu bölgeye eğitim ve sağlık için gelen kişilerin bölgede kalıcı olmadığı şeklinde yorumlanabilir.

Göç veren bölgeler için gerçekleştirilen tahmin sonuçlarında ise; kişi başına düşen gayri safi yurt içi hâsıla Türkiye ortalamasının altında kaldığından bu bölgelerde negatif etkiye sahiptir. Göç veren bölgelerdeki işsizlik sayısının artması göç edenlerin sayısının da artmasına neden olmuştur. Üretim ve eğitim seviyesinin bu bölgelerde düşük olması göçün itici unsurunu arttırmıştır. Bu açıdan ithal edilen mal ve hizmetin sayısı bu bölgelerde fazla olmuştur. Benzer yorum, herhangi bir okul bitirmeyen kişi sayısı için de aynı olacaktır. Sağlık alanındaki gelişmelerin olumsuz yaşandığı göç veren bölgelerde yeterli hastane yatak sayısının olmayışı yine bu bölgede insanların göç etmesine sebebiyet vermiştir. En önemli sonuçlardan biri, göç veren bölgelerde işlenen tarım arazilerinin giderek azalması, göç üzerinde ciddi bir etki oluşturmuştur. Bu açıdan, göç veren bölgelerin diğer bölgelere göre kırsal bölgeler olması ve tarımın bu alanlarda önemli gelir kapısı olarak görüldüğü düşünüldüğünde, göç veren bölgelerin tarım arazilerinin üretime hazır hale getirilmesi, göç sayısını düşürmede ciddi bir politika aracı olacaktır.

Göç olgusunun temelinde yatan hızlı nüfus artışının durdurulması ve uzun dönemde üretimden sağlanan kazancın arttırılması, bölgesel gelir dengesizliğinin giderilmesinde ve iyileştirilmesinde oldukça gereklidir. Bu sebeple spesifik olarak göç veren bölgelerde tarım, sanayi, sağılı ve eğitim alanında gerçekleştirilecek yatırımlar ve iyileştirici politikalar bu bölge insanları açısından istihdamda sürekliliği sağlayacaktır. Dolayısıyla, kamu ve özel yatırımların bu bölgelerde sıklaştırılması ve teşvik edilmesi, sağlam sosyal ve ekonomik politikaların uygulanmasıyla mümkün olacaktır.

\section{Beyan ve Açıklamalar (Disclosure Statements)}

1. Bu çalışmanın yazarları, araştırma ve yayın etiği ilkelerine uyduklarını kabul etmektedirler (The authors of this article are admitted that they complied with the principles of research and publication ethics).

2. Yazarlar tarafından herhangi bir çıkar çatışması beyan edilmemiştir (No potential conflict of interest was reported by the authors).

3. Bu çalışma, intihal tarama programı kullanılarak intihal taramasından geçirilmiştir (This article was screened for potential plagiarism using a plagiarism screening program).

\section{Son Notlar}

1. Göç Veren: Akdeniz, Orta Anadolu, Batı Karadeniz, Doğu Karadeniz, Kuzeydoğu Anadolu, Ortadoğu Anadolu, Güneydoğu Anadolu

Göç Alan: İstanbul, Batı Marmara, Ege, Doğu Marmara, Batı Anadolu

\section{Kaynaklar}

Abar, H. (2014). Türkiye'de iller arası göç: Mekânsal panel model yaklaşımı. Atatürk Üniversitesi Sosyal Bilimler Enstitüsü, Doktora Tezi, Erzurum.

Akseki, U., \& Türkcan, B. (2016). Türkiye'de bölgesel göç, konut ve işgücü piyasaları üzerine panel nedensellik analizleri. International Congress of Management Economy and Policy (ICOMEP). 26-27 November, Istanbul. https://www.icomep.com/pdf/Volumell.pdf (Erişim Tarihi: 27.12.2019). 
Albayrak, N., \& Abdioğlu, Z. (2017). Türkiye'de iç göçü etkileyen faktörlerin analizi. Researcher: Social Science Studies, 5(10), 293-309.

Anavatan, A. (2017). Türkiye'de iç göç ve belirleyicileri: Mekânsal veri analizi. Social Sciences Studies Journal (SSSJ), 3(6), 1109-1116.

Ankara Kalkınma Ajansı (2014). Ankara göç analizi. Araştırmalar Serisi-5, 1-41.

Anselin, L. (1988). Spatial econometrics: Methods and model. Kluwer Academic Publishers, Boston/London.

Anselin L., \& Florax, R. (1995). Small sample properties of tests for spatial dependence in regression models. In L. Anselin and R. Florax (Eds). New direetions in spatial econometries (pp. 3- 18). Berlin: Springer-Verlag.

Anselin, L. (1998). Spatial dependence in linear regression models with an introduction to spatial econometrics. In A. Ulah and D. Giles (Ed.), Handbook of applied economic statistics. New York: Marcel Dekker.

Anselin, L. (2003). Spatial externalities, spatial multipliers and spatial econometrics. International Regional Science Review, 26(2), 153-166.

Aşkın, E.Ö., Yayar, R., \& Oktay, Z. (2013). Kırsal göçün ekonometrik analizi: Yeşilyurt ilçesi örneği. Cumhuriyet Üniversitesi iktisadi ve Idari Bilimler Dergisi, 14(2), 231-252.

Bahar, O., \& Bingöl, F. (2010). Türkiye'de iç göç hareketlerinin istihdam ve işgücü piyasalarına etkileri. Süleyman Demirel Üniversitesi Iktisadi ve Idari Bilimler Fakültesi Dergisi, 15(2), 43-61.

Bindak, R. (2015). iller arası göç tahmini için bir çekim (cazibe) modeli önerisi. Social Sciences Research Journal, 4(2), 111-120.

Bülbül, S., \& Köse, A. (2010). Türkiye'de bölgelerarası iç göç hareketlerinin çok boyutlu ölçekleme yöntemi ile incelenmesi. İstanbul Üniversitesi İşletme Fakültesi Dergisi, 39(1), 75-94.

Çetin, D. (2012). Exports and clusters: A Spatial econometric analysis on Ankara and istanbul oizs (Ph.D.). Middle East Technical University, Ankara.

Çetin, i., \& Çetin, S. (2018). Türkiye'de iç göçün belirleyicilerinin analizi. Yönetim ve Ekonomi Araştırmaları Dergisi, 16(1). 98-115.

Doğan, M. G., \& Kabadayı, A. (2015). Determinants of internal migration in Turkey: A Panel data analysis approach. Border Crosing, 5(1-2), 16-24.

Dücan, E. (2016). Türkiye'de iç göçün sosyo-ekonomik nedenlerinin bölgesel analizi. Ekonomik ve Sosyal Araştırmalar Dergisi, 12(2), 167-183.

Ercilasun, M., Hiç Gencer, A., \& Ersin, Ö. (2011). Türkiye'deki iç göçleri belirleyen faktörlerin modellenmesi. International Conference on Eurasian Economies. http://avekon.org/papers/378.pdf (Erişim Tarihi: 27.12.2019).

Karakayacı, Z., Oğuz, C., \& Öz, A. (2018). A Research on the tendency of re-migration to rural area: A case study of Karatay District in Konya province (Turkey). Selcuk Journal of Agriculture and Food Sciences, 32(3), 523-529.

Karpat Ç., G., \& Yarar, Ö. (2015). Türkiye'deki bölgeler arası iç göçü etkileyen faktörlerin panel veri analizi ile belirlenmesi. Alphanumeric Journal, 3(1), 99-117.

Manavgat, G., \& Saygılı, R. F. (2016). Türkiye'de iç göçü etkileyen faktörler üzerine bir uygulama: Mekânsal panel veri analizi. 2nd International Conference on Applied Economics and Finance (ICOAEF), 5-6 December, Girne, North Cyprus. http://www.icoaef.com/wp-content/proceedings/Proceedings\%202.pdf (Erişim Tarihi: 27.12.2019).

Özcan, D. E. (2016). Çağdaş göç teorileri üzerine bir değerlendirme. İş ve Hayat, 2(4), 183-215.

Özdemir, D. (2018). Türkiye'de bölgelerarası iç göç hareketlerinin belirleyicileri. Atatürk Üniversitesi Sosyal Bilimler Enstitüsü Dergisi, 22(3), 1337-1349.

Pazarlıŏlu, M. V. (2007). İzmir örneğinde iç göçün ekonometrik analizi. Celal Bayar Üniversitesi, iktisadi ve Idari Bilimler Fakültesi, Yönetim ve Ekonomi, 14(1), 121-135.

Sevinç, G., Kantar, D., M., \& Sevinç, M. R. (2018). Türkiye'de kırdan kente göç ve göçün aile üzerindeki etkileri. Iktisadi idari ve Siyasal Araştırmalar Dergisi, 3(6), 70-82.

Sevinç, G., Kaya, K., Asoğlu, V., \& Sevinç, M. R. (2014). Türkiye'de kırdan kente göç ve göçün aile üzerindeki etkileri. XI. Ulusal Tarım Ekonomisi Kongresi, 3-5 Eylül, Samsun, Türkiye, http://web.hitit.edu.tr/dosyalar/yayinlar/gungorkarakas@hititedutr110320177B4N6X7Z.pdf (Erişim Tarihi: 27.12.2019).

Sigeze, Ç., \& Ballı, E. (2016). The determinants of internal migration: The case of Turkey. International Journal of Economics and Finance Studies, 8(2), 292-303.

Şen, M. (2014). Türkiye'de iç göçlerin neden ve sonuç kapsamında incelenmesi. Çalışma ve Toplum, 1, 231-256. 
Tatlı, S. (2016). Mekânsal ekonometrik modeller ve Türkiye’de iç göçün belirleyicilerinin analizi. İstanbul Üniversitesi Sosyal Bilimler Enstitüsü, Yüksek Lisans Tezi, İstanbul.

T. C. Kalkınma Bakanlığı (2014). Onuncu kalkınma planı 2014-2018. Özel ihtisas komisyonu raporu, Göç, Ankara.

Temel, R. (2017). Doğu ve güneydoğudan göç eden bireylerin yoksulluk ve sosyal dışlanma boyutunda incelenmesi (Manisa ili örneği). Pamukkale Üniversitesi Sosyal Bilimler Enstitüsü, Yüksek Lisans Tezi, Denizli.

Topbaş, F. (2007). İç göçün belirleyicileri üzerine ekonometrik bir model çalışması: 2000 Türkiye örneği. Karadeniz Teknik Üniversitesi Sosyal Bilimler Enstitüsü, Doktora Tezi, Trabzon.

Türkiye İstatistik Kurumu (TÜiK), www.tüik.gov.tr (Erişim Tarihi: 27.12.2019).

Yakar, M. (2012). Türkiye'de iç göçlerin ilçelere göre mekânsal analizi: 1995-2000 dönemi. Uluslararası Insan Bilimleri Dergisi, 9(1), 742-768.

Yayar, R., Uçgunoğlu, M., \& Demir, Y. (2016). Türkiye'de iç göçün belirleyicileri. International Conference on Eurasian Economies. https://www.avekon.org/papers/1513.pdf (Erişim Tarihi: 27.12.2019).

Yerdelen Tatoğlu, F. (2017). Determining the factors that affect the net migration rate in Turkey with ordered panel logit regression analysis. Doğuş Üniversitesi Dergisi, 18(1), 1-13. 
This Page Intentionally Left Blank 